\title{
Multi-drug resistance gene (MDR1) and opioid analgesia in horses
}

\author{
Gene de resistência múltipla aos fármacos e analgesia opióide em eqüinos
}

\author{
Cláudio Corrêa Natalini ${ }^{1}$ Anderson Fávaro da Cunha ${ }^{1}$ Renata Lehn Linardi ${ }^{1}$
}

\section{- REVIEW -}

\begin{abstract}
Opioid absorption in the intestinal tract as well as its effects in the central nervous system is modulated by the $P$ glycoprotein (P-gp) encoded in the Multi-drug Resistance gene (MDR1) also named ATP-binding cassete, subfamily B, member 1 (ABCB1). This MDR1 gene acts as a selective pump. The expression of this protein in humans and rodents inhibits cellular uptake of substrate opioids. The presence of the intestinal isoenzyme CYP3A4 associated with MDR1 gene decreases the opioid analgesic activity due to an increase in intestinal metabolism, with a predicted intestinal first pass extraction around $20 \%$ which significantly influences the oral availability of opioids. In the central nervous system, P-gp expression decreases opioid neuronal uptake diminishing the analgesic effects. It is unknown if horses have the MDRl gene and P-gp and what are the effects on opioid absorption, metabolism, and analgesia. Identifying the MDRI gene and P-gp status in horses is of great importance in order to better understand opioid pharmacologic effects in horses.
\end{abstract}

Key words: molecular biology, opioids, equine, gene, MDRl, $A B C B 1$, analgesia.

\section{RESUMO}

A absorção de opióides no trato intestinal, assim como seus efeitos no sistema nervoso central, são modulados pela P-glicoproteína ( $P$-gp), uma proteína de membrana celular codificada pelo gene MDR1, também chamado ATPbinding cassete, subfamília $B$, membro 1 (ABCB1) e que atua como bomba seletiva. A expressão desta proteína em roedores e seres humanos inibe a absorção celular de opióides e sua presença no intestino associada à isoenzima CYP3A4 reduz a atividade analgésica dos opióides por ativação do metabolismo intestinal do fármaco. A redução na extração intestinal de fármacos opióides susceptíveis a esta proteína chega a 20\%, o que reduz significativamente a biodisponibilidade de opióides administrados por via oral. No sistema nervoso central, a P-gp diminui a captação neuronal dos opióides e seus efeitos analgésicos. Ainda é desconhecido se o gene MDRl e a P-gp estão presentes no trato intestinal e no sistema nervoso central em cavalos e quais os seus efeitos na absorção, metabolismo e efeito analgésico nesta espécie. Fica evidente a importância da determinação da presença ou não deste gene e sua expressão protéica no cavalo, para um melhor entendimento da farmacologia dos opióides nesta espécie.

Palavras-chave: biologia molecular, opióides, eqüino, gene, MDR1, ABCB1, analgesia.

\section{INTRODUCTION}

Pain inhibition has been under discussion since the earliest records of medicine. Galen (AD 129199), one of the most important physicians in the history of medicine wrote in his first book: "Divinum est opus sedare dolorem". In equine medicine it is not different, providing effective analgesia for horses to reduce the postoperative morbidity associated with orthopedic or soft-tissue injuries remains challenging. The limited efficacy of currently available analgesic

${ }^{1}$ Department of Veterinary Clinical Sciences, Louisiana State University, Baton Rouge, LA 70803, USA. Email: cnatalini@vetmed.lsu.edu Author correspondence (Natalini). 
agents and the adverse effects associated with their use, narrow the applicability of these drugs (CLARKE \& PATON, 1988).

In the past, analgesia in animals was avoided for several reasons (HACKETT, 1976) however, pain itself has deleterious effects on convalescence and has an economic impact once longer hospitalization periods translates in higher costs. In addition, the concept that administering analgesia to the equine patient could cause a loss of the protective reflexes thereby raising the risk of self injury often led to withholding of drugs (TAYLOR et al., 2002). In recent years attitudes are changing, partially as a result of the recent emphasis on pain recognition and management in the veterinary medicine (TAYLOR et al., 2002). However, investigation of analgesia in horses has been limited mainly to pharmacokinetic studies of drugs and the effects of these drugs in experimental models of induced pain (SELLON et al., 2004).

Pain management in horses is based almost exclusively on non-steroidal anti-inflammatory drugs (NSAIDs). However, the effectiveness of NSAIDs as an analgesic itself has never been tested (TAYLOR et al. 2002).

Although opioid drugs will not prevent or treat inflammation, they are the most potent pain relieving substances known, but these drugs are not extensively used in horses because marked sympathetic stimulation and central nervous system (CNS) excitation when intravenously administered as classically described by KAMERLING et al. (1985). Providing effective analgesia in horses with orthopedic and soft-tissue injuries remains challenging because of the limited efficacy of currently available analgesic agents and the risk of adverse effects associated with their use (KAMERLING, 1998).

The objective of this review was to gather information on the influence of the MDR1 gene and opioid analgesia in horses.

Multi-drug (MDR1) resistance gene and drug disposition

Drug disposition such as absorption, distribution, metabolism, and excretion may be altered by different factors already established in the literature. Major factors able to alter drug absorption from the intestinal lumen or the ability of drugs to cross barriers such as blood-brain and blood-placenta barriers pertain to physicochemical properties of the drug (e.g. pKa, molecular weight, lipophilicity, solubility, degree of ionization) and biological factors (e.g. gastric and intestinal transit time, luminal $\mathrm{pH}$, mucosal blood flow, protein binding) (LIN et al., 2003; WANDEL et al., 2002).
P-glycoprotein (P-gp) is a plasma membrane protein also named "permeability glycoprotein" and encoded by the multi-drug resistance (MDR1) gene. This protein was first identified by JULIANO \& LING (1976) in mammalian tumor cells resistant to multi anticancer agents. Although P-gp is over expressed in tumor cells, it is also expressed in normal tissues (intestinal epithelium cells, hepatic cells, renal tubule cells, and endothelial cells of the placenta and brain blood-tissue-barriers) (SCHINKEL et al., 1996).

P-glycoprotein acts as an energydependent efflux pump exporting substrates from intracellular to extracellular domain (FROMM, 2004). P-glycoprotein can confer multi-drug resistance by actively extruding a wide range of structurally unrelated drugs from the cell. Many of these drug substrates are toxic compounds of natural or semi-synthetic origin (plants, fungi, bacteria), which are extensively used in the chemotherapy of cancer (e.g., Vinca alkaloids, anthracyclines, epipodophyllotoxins, actinomycin D, taxanes) or for a variety of other medical purposes such as immune-suppression (cyclosporinee A, FK506) (JAMES et al., 2002).

The P-glycoprotein reduces drug absorption from gastrointestinal tract once the drug has reached the blood circulation and enhances drug elimination into the bile and urine as a result of its expression in the luminal intestine, canalicular membrane of hepatocytes, and luminal membrane of proximal tubule cells in the kidneys. This protein also acts by blocking the entry of certain drugs into the CNS and certain sensitive tissues such as fetal circulation, lymphocytes, and testis (FROMM, 2004).

The importance of P-glycoprotein was showed when a group of researchers was working with knockout MDR1 (-/-) mice. Shortly after they obtained the first MDR1 (-/-) mice (and by pure coincidence) they discovered that these mice were extremely sensitive to ivermectin. Following a mite infestation all their mice were sprayed with a diluted solution of ivermectin, which is considered a safe procedure. A number of mice died with paralytic symptoms, and subsequent tail DNA analysis proved that only MDR1 (-/-) mice had died, and no (+/+) or (+/-) mice had the same neurological problems. A systemic toxicity analysis demonstrated that MDR1 (-/-) mice are 50- to 100-fold more sensitive to orally administered ivermectin (SCHINKEL et al., 1994) than wild type or heterozygous mice.

Extreme ivermectin sensitivity has been reported in collie breed dogs. The lethal oral dose was approximately $0.4 \mathrm{mg} \mathrm{kg}^{-1}$, as opposed to approximately $80 \mathrm{mg} \mathrm{kg}^{-1}$ in other dogs. Hypersensitivity was 
associated with highly increased ivermectin accumulation in the brain. An analogy was created between the MDR1 (-/-) mice and the Collie dogs by SCHINKEL et al. (1996).

$\mathrm{P}$-glycoprotein expression is believed to be an important component of the blood-brain barrier as a protective mechanism against potentially toxic xenobiotics, capable of actively pumping a variety of drugs out of the CNS (CORDON-CARDO et al., 1989; FROMM, 2004).

Drugs that are not themselves substrates for P-gp but may nevertheless inhibit P-gp are a potential source of important drug interactions that can produce an increased penetration into the CNS of concomitant drugs that are P-gp substrates such as loperamide, digoxin, and cyclosporine. Human immunodeficiency has the potential to affect drug pharmacokinetics broadly, altering control drug distribution to tissues such as the brain and testis, but also drug elimination by kidney and biliary tract and bioavailability via the gastrointestinal tract (JAMES et al., 2002).

P-glycoprotein has been hypothesized to modulate intestinal drug metabolism by increasing the exposure of drug to intracellular enzyme cytochrome CYP3A4 through repeated cycles of drug absorption and efflux (CUMMINS et al., 2003).

Most of these P-glycoprotein substrates are also substrates of the major drug-metabolizing CYP3A4. However, it should be noted that this overlap is not complete because some drugs are transported by $\mathrm{P}-\mathrm{gp}$ but are not metabolized by CYP3A4 (e.g. digoxin) and some compounds are CYP3A4 substrates but are not P-gp substrates (e.g. midazolam) (CUMMINS et al., 2003).

However, enterocytes and hepatocytes, simultaneously express the major drug metabolism enzyme CYP3A4 and the efflux transporter Pglycoprotein. This leads to a drug efflux-metabolism alliance, which increases the access of drug to metabolism by CYP3A4 through repeated cycles of absorption and efflux including opioids (LYKKESFELDT et al., 1994).

Chronic anticancer therapy often induces P-gp expression in cancer cells, resulting in decreased intracellular concentrations of such agents, decreased in therapeutic effect, and resistance to anticancer treatment. Blockade of the pump by inhibition with specific inhibitors (e.g., PSC-833) and also widely used drugs, including cyclosporine, quinidine, and verapamil, has been used as a strategy to reverse MDR1 gene expression (TSURUO \& FIDLER, 1981). Blockade of P-gp allows enhanced CNS entry of some drugs, (SCHINKEL et al., 1994) offering new possibilities to explain CNS-related adverse effects during the administration of drugs substrates of P-gp and furthermore, to manipulate the CNS entry of drugs (WOOD, 1997).

Cyclosporine was shown by THOMPSON, et al. (2000) to be a P-glycoprotein inhibitor. When fentanyl was administered together with cyclosporine in mice these authors observed improvements in analgesia. Morphine has also been shown to increase analgesia in P-gp knockout mice compared with wildtype mice. Thus, P-glycoprotein may limit morphine entry into the brain. Some authors suggest that in the future as new drugs are introduced into clinical practice, it will be important to assess whether they are P-gp substrates or inhibitors to assess their potential for drug interaction. Inter-individual variability in P-gp activity is already recognized, which may at least partially, depend on genetic polymorphism (WANDEL et al., 2002).

In one study, oral administration of loperamide with quinidine resulted in CNS effects although loperamide is a potent opiate which does not produce CNS effects at anti-diarrheal doses (SCHINKEL et al., 1994). Quinidine is a substrate for Pgp that can interact with other drugs and inhibit this protein. Inhibition of intestinal P-glycoprotein increases entry of loperamide into the CNS with resultant respiratory depression. This apparent tissue selectivity is probably a result of loperamide being a P-gp substrate, so this protein in the CNS effectively prevents access of loperamide to the CNS. In support of this hypothesis, knockout MDR1 mice had brain loperamide concentrations eightfold higher than those observed in normal mice, and lethal opioid effects were produced (SCHINKEL et al., 1994). In humans, the coadministration of loperamide with the P-gp inhibitor quinidine results in respiratory changes (SADEQUE et al., 2000).

WANDEL et al. (2002) observed that morphine is a relatively poor $\mathrm{P}$-gp substrate if compared with loperamide. After oral administration of methadone in mice, absorption from the gastrointestinal tract is modulated by the MDR1 gene and the P-gp (MUKHOPADHYAY, 2003).

Methadone and other $\mathrm{OP}_{3}$ opioids in horses

Opioids have been administered clinically to horses for at least seventy years (BENNET \& STEFFEY, 2002). However, horses differ in their responses to opioids when compared to dogs and humans. Horses experiencing acute pain commonly react to opioid analgesics with increased locomotor activity and excitement at doses that would cause 
sedation in dogs. Morphine, fentanyl, and methadone, all $\mathrm{OP}_{3}$ ( $\mu$-opioid) agonists, may induce marked locomotor activity in horses, with morphine inducing the greatest increase in locomotion when administered intravenously or intramuscularly, restricting the utilization of opioids in this species.

Epidural injection of opioids produce long lasting and potent analgesia without CNS excitement but the effect is limited to the hind limbs, perineal and sacral regions (NATALINI \& ROBINSON, 2000). Even among $\mathrm{OP}_{3}$ agonists, differences in side-effects occur with different drugs. One study comparing opiate and alpha-2 adrenergic receptor binding using radioligand autoradiography showed that receptor distribution is not the same in horses and in dogs (HELLYER et al. 2003). We need to understand the relevance of these findings in vivo and under clinical conditions to clarify the information about different opioid receptor populations in the horse.

Methadone is a synthetic opioid agonist used to treat moderate to severe pain in humans (MORLEY et al., 2003), cats (ROBERTSON \& TAYLOR, 2004), dogs and epidurally in horses (OLBRICH \& MOSING, 2003). Methadone is extensively used to treat the abstinence syndrome in human patients who are dependent on heroin and other opioids (BOULTON et al., 2001). Besides its $\mathrm{OP}_{3}$ agonist effects, methadone has an additional noncompetitive antagonist activity at the N-methyl-D-aspartate receptors (NMDA). It is marketed as a racemic (R/S) mixture (BOULTON et al., 2001). The R-enantiomer binds more specifically the $\mathrm{OP}_{3}$ receptors eliciting most of the therapeutic and adverse effects and, the L-enantiomer bind more specifically to the NMDA receptors (SHIMOYAMA et al., 1997).

Blocking the NMDA receptor causes an antinociception effect in a variety of animal pain models (SHIMOYAMA et al., 1997). The NMDA receptor plays an important role in pain transmission by modulating both "wind-up," a physiological phenomenon whereby spinal cord neurons became abnormally active after repetitive $\mathrm{C}$-fiber stimulation and central sensitization, the more general phenomenon whereby sensory neurons decrease activation thresholds, enlarge receptive field size and fire spontaneously in the aftermath of noxious peripheral stimulation (WOOLF \& THOMPSON, 1991; DUBNER \& RUDA, 1992).

The adverse effects associated with methadone administration in people are nausea, vomiting, headache, drowsiness, visual hallucinations, photophobia, and lightheadedness (BOULTON et al., 2001). The pharmacokinetic and dynamic of methadone are characterized by high interindividual variability in people (BOULTON et al., 2001). The pharmacokinetic and dynamic of methadone are unknown for the equine species.

Methadone is a lipid-soluble basic drug with a pKa of 9.2. In human beings, after oral administration, it can be detected in the blood as soon as 15-45 minutes. The peak plasma concentration occurs at 2.5 to 4 hours after dose intake with some differences among patients (range 1-5 hours), but independently of the dose. A second plasma peak may be detected 4 hours after administration and probably is due to enterohepatic recirculation.

Methadone has been used in combination with phenothiazines or other tranquilizers and sedatives in horses since 1967 (SCHAUFFER, 1969). Also it has been administered epidurally and systemically to treat pain in horses. In a study comparing intravenous morphine and methadone in horses, the authors observed less euphoria after administration of $1.1 \mathrm{mg} . \mathrm{kg}^{-1}$ of methadone compared to $0.12 \mathrm{mg} \mathrm{kg}^{-1}$ of morphine with similar effects on the cardiac output, heart rate, and respiratory rate (MUIR et al., 1978). DODMAN (1980) observed profound and reliable chemical restraint when methadone in combination with tranquilizers was administrated as a pre-anesthetic in horses. Since 1999, methadone has been included in the list of controlled drugs and should be considered in the doping control, due to the misuse of opiates in racehorses in the past (HAGEDORN et al., 1999). Unfortunately methadone carries a stigma related to its use in opioids addiction programs (WALL \& MELZACK, 1999).

The presence of intestinal CYP3A4 decreases the analgesic activity of methadone in human beings and rodents due to intestinal metabolism, with a predicted intestinal first pass extraction around $20 \%$ which significantly influences the oral availability of methadone (EAP et al., 2002). In one study it was found that the analgesic efficacy of morphine, methadone, and fentanyl was be increased in animals that lack P-gp, suggesting that P-gp plays an important role in limiting access of these drugs to the brain (THOMPSON et al., 2000; BAI et al., 2004, MEALEY, 2004). It is unknown if horses have the MDR1 gene and how this gene expresses regarding $\mathrm{P}$-gp activation and its effects on methadone absorption, metabolism, and analgesic effects. MUKHOPADHYAY et al. (1988) observed in a study with Chinese hamster that P-gp plays a role in detoxification by pumping potentially harmful compounds into the lumen of digestive tracts in animals.

Because there are no reports on oral methadone or a complete pharmacokinetic study in 
horses it is unknown how it will affect gastro-intestinal motility. Isolated preparations of equine ileum and pelvic flexure can be used for in vitro studies to show how the methadone or other opioid may affect motility patterns in equine intestine (GERRING, 1989 and DAVIES \& GERRING, 1983). In rats the highest level of expression of MDR1 gene was observed in the gastrointestinal tract, with levels increasing, respectively, from duodenum, jejunum, and ileum to large intestine. Expression levels of MDR1 gene in the cerebral cortex, cerebellum, kidney, lung and liver were less than one-tenth of that in the ileum (BRADY et al., 2002).

\section{CONCLUSION}

Future studies on MDR1 gene in horses are granted. The determination of the MDR1 gene status in horses may explain the CNS side effects of the opioids and elucidate the impact of the P-glycoprotein on oral administration of these drugs, contributing to the knowledge regarding pain management in the equine species.

\section{REFERENCES}

BAI, J.et al. In vitro detection of MDR1 mRNA in murine leukemia cells with $111 \mathrm{In}$-labeled oligonucleotide. European Journal of Nuclear Medicine Molecular Imaging, Berlim, v.31, n.11, p.1523-1529, 2004.

BENNETT R.C.; STEFFEY E.P. Use of opioids for pain and anesthetic amangement in horses. Veterinary Clinics of North America: Equine Practice, Philadelphia, v.18, p.4760, 2002.

BOULTON, D.W. et al. Pharmacokinetics and pharmacodynamics of methadone enatiomers after a single oral dose of racemate. Clinical Pharmacology \& Therapeutics, St. Louis, v.70, n.1, p.48-57, 2001.

BRADY J.M. et al. Tissue distribution and chemical induction of multiple drug resistance genes in rats. Drug Metabolism Disposition, Baltimore, v.30, n.7,p.838-844, 2002.

CLARKE K.W.; PATON B.S. Combined use of detomidine with opiates in the horse. Equine Veterinary Journal, London, v.20, n.1, p.331-334, 1988.

CORDON-CARDO C. et al. Multidrug-resistance gene (Pglycoprotein) is expressed by endothelial cells at blood-brain barrier sites. Proceedings of the National Academy of Sciences of the United States of America, Washington, v.86, n.2, p.695-698, 1989.

CUMMINS C.L. et al. In vivo modulation of intestinal CYP3A metabolism by P-glycoprotein: studies using the rat single-pass intestinal perfusion model. Journal of Pharmacology and Experimental Therapeutics, Baltimore, v.305, n.1, p.306$314,2003$.
DAVIES, J.V.; GERRING, E. L. Effect of spasmolytic analgesic drugs on the motility patterns of the equine small intestine. Research in Veterinary Science, Oxford, v.34, p.334-339, 1983.

DODMAN N.H. Chemical restraint in the horse. Equine Veterinary Journal, London, v.12, n.4, p.166-170, 1980.

DUBNER R.; RUDA M.A. Activity-dependent neuronal plasticity following tissue injury and inflammation. Trends in Neurosciences, Amsterdam, v.15,n.3, p.96$103,1992$.

EAP C.B. et al. Interindividual variability of the clinical pharmacokinetics of methadone. Clinical Pharmacokinetics, New York, v.41, n.14, p.1153-1193, 2002.

FROMM M.F. Importance of P-glycoprotein at blood-tissue barriers. Trends in Pharmacoligal Sciences, Amsterdam, v.25, n.8, p.423-429, 2004.

GERRING E.L. Effects of pharmacological agents on gastrointestinal motility. Veterinary Clinics of North America: Equine Practice, Philadelphia, v.5, n.2, p.283294, 1989.

HACKETT R.P. Analgesics for horses. Veterinary Anaesthesia, Oxford, v.3, n.2, p.116-120, 1976.

HAGEDORN H.W. et al. Methadone screening of racehorses. Journal of Analytical Toxicology, Niles, v.23, n.7, p.609$614,1999$.

HELLYER P.W. et al. Comparison of opioid and alpha-2 adrenergic receptor binding in horse and dog brain using radioligand autoradiography. Veterinary Anaesthesia and Analgesia. Oxford, v.30, p.172-182, 2003.

JAMES M. et al. Tissue distribution and chemical induction of multiple drug resistance genes in rats. Drug metabolism and disposition: the biological fate of chemicals, Baltimore, v.30, n.7, p.838-844, 2002.

JULIANO R.L.; LING, V. A suface glycoprotein modulating drug permeability in Chinese hamster ovary cell mutants. Biochimica et Biophysica Acta, Amsterdam, v.455, p.152162,1976 .

KAMERLING S. Dose related effects of the kappa agonist U$50,488 \mathrm{H}$ on behavior, nociception and autonomic response in the horse. Equine Veterinary Journal, Oxford, v.20, n.2, p.114-118, 1998.

KAMERLING S. G. et al. A method for studying cutaneous pain perception and analgesia in horses. Journal of Pharmacological Methods, New York, v.13, p.267-274, 1985 .

LIN J.H. et al. Role of P-glycoprotein in pharmacokinetics: clinical implications. Clinical Pharmacokinetics, New York, v.42, p.59-98, 2003.

LYKKESFELDT J. et al. Simultaneous determination of urinary free cortisol and 6 $\beta$-hydroxycortisol by high-performance liquid chromatography to measure human CYP3A activity. Journal of chromatography. B, Biomedical sciences and applications, Amsterdam, v.660, p.23-29, 1994. 
MEALEY K.L. Therapeutic implications of the MDR-1 gene. Journal Veterinary Pharmacology \& Therapeutics, Oxford, v.27, n.5, p.257-64, 2004

MORLEY J.S. et al. Low-dose methadone has an analgesic effect in neuropathic pain: a double-blind randomized controlled crossover trial. Palliative Medicine, London, v.17, n.7, p.576-87 2003 .

MUIR W.W. et al. Cardiopulmonary effects of narcotic agonists and a partial agonist in horses. American Journal of Veterinary Research, Chicago, v.39, n.10, p.1632-1635, 1978.

MUKHOPADHYAY T. et al. Expression of the MDR (Pglycoprotein) gene in Chinese hamster digestive tracts. Journal of the National Cancer Institute, Bethesda, v.80, n.4, p.269$275,1988$.

NATALINI C.C.; ROBINSON E.P. Evaluation of the analgesic effects of epidurally administered morphine, alfentanil, butorphanol, tramadol, and $\mathrm{U} 50488 \mathrm{H}$ in horses. American Journal of Veterinary Research, Chicago, v.61, n.12, p.1579-1586, 2000.

OLBRICH V.H.; MOSING M. A comparison of the analgesic effects of caudal epidural methadone and lidocaine in the horse. Veterinary Anaesthesia and Analgesia, Oxford, v.30, n.3, p.156-164, 2003.

ROBERTSON S.A.; TAYLOR P.M. Pain management in cats past, present and future. Part 2. Treatment of pain - clinical pharmacology. Journal of Feline Medicine and Surgery, London, v.6, n.5, p.321-33, 2004.

SADEQUE A.J. et al. Increased drug delivery to the brain by Pglycoprotein inhibition. Clinical Pharmacology \& Therapeutics, St. Louis, v.68, n.3, p.231-237, 2000.

SCHAUFFER A.F. Acetylpromazine + methadone $=$ better equine restraint. Modern Veterinary Practice, Wheaton, v.50, p.46-49, 1969

SCHINKEL A.H. et al. Disruption of the mouse MDR-1 a Pglycoprotein gene leads to a deficiency in the blood-brain barrier and to increased sensivity to drugs. Cell, Cambridge, v.77, p.491-502, 1994

SCHINKEL A.H. et al. P-glycoprotein in the blood-brain barrier of mice influences the brain penetration and pharmacological activity of many drugs. Journal of Clinical Investigation, New Haven, v.97, n.11, p.2517-2524, 1996.

SELLON D.C. et al. Effects of continuous rate intravenous infusion of butorphanol on physiologic and outcome variables in horses after celiotomy. Journal of Veterinary Internal Medicine, Philadelphia, n.18, n.4, p.555-563, 2004.

SHIMOYAMA N. et al. D-Methadone is antinociceptive in the rat formalin test. Journal of Pharmacology and Experimental Therapeutics, Baltimore, v.283, n,2, p.648652, 1997.

TAYLOR P.M. et al. Diagnosing and treating pain in the horse. Where are we today? Veterinary Clinics of North America: Equine Practice, Philadelphia, n.18, n.1, p.1-19, 2002.

THOMPSON S.J. et al. Opiate-induced analgesia is increased and prolonged in mice lacking P-glycoprotein. Anesthesiology, Philadelphia, v.92, n.5, p.1392-1399, 2000.

TSURUO T.; FIDLER I.J. Differences in drug sensitivity among tumor cells from parental tumors, selected variants, and spontaneous metastases. Cancer Res, Philadelphia, v.41, n.8, p.3058-3054, 1981

WALL P.D.; MELZACK A.R. Textbook of pain. 4.ed. Edinburgh: Churchill Livingstone, 1999. 1280p.

WANDEL C. et al. Interaction of morphine, fentanyl, sufentanil, alfentanil, and loperamide with the efflux drug transporter P-glycoprotein. Anesthesiology, Philadelphia, v. 96, n.4, p.913-920, 2002

WOOD M. Drug distribution: less passive, more active? Anesthesiology, Philadelphia, v.87, n.6, p.1274-1276, 1997.

WOOLF C.J.; THOMPSON S.W. The induction and maintenance of central sensitization is dependent on N-methylD-aspartic acid receptor activation; implications for the treatment of post-injury pain hypersensitivitystates. Pain, Amsterdam, v.44, n.3, p.293-299, 1991. 